\title{
MICROPROPAGATION, SEED PROPAGATION AND GERMPLASM BANK OF Mandevilla velutina (Mart.) WOODSON
}

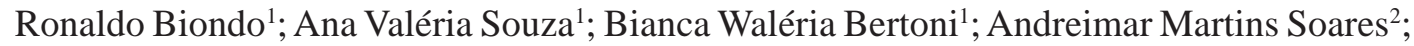 \\ Suzelei Castro França ${ }^{1}$; Ana Maria Soares Pereira ${ }^{1 *}$ \\ ${ }^{1}$ UNAERP - Unidade de Biotecnologia, Costábile Romano, 2201 - 14096-900 - Ribeirão Preto, SP - Brasil. \\ ${ }^{2}$ USP/FCFRP, Depto. de Análises Clínicas Toxicológia e Bromatologia, Av. do Café, s/no ., Campus Universitário \\ da USP - 14040-903 - Ribeirão Preto, SP - Brasil. \\ *Corresponding author <apereira@unaerp.br>
}

ABSTRACT: Mandevilla velutina (Mart.) Woodson (Apocynaceae) is a medicinal plant species with antivenom properties, native from Brazilian Savanna regions (Cerrado), which due to overexploitation and habitat deforestation is in danger of extinction. As an initiative for conserving this endangered but economically important plant species, a micropropagation protocol was developed and genotypes were stored in the Germplasm Bank "Cerrado In vitro". For the in vitro propagation of M. velutina, nodal segments were inoculated on Murashige and Skoog (MS) medium supplemented with different concentrations of BA, Zeatin, 2ip, DTT and TDZ. Best multiplication ratio was achieved when to the medium 0.44 $\mu \mathrm{M}$ BA, ranging 1: 6.7, were added. Plantlets cultured on MS/2 medium supplemented with $26.85 \mu \mathrm{M}$ NAA rooted successfully (50.5\%). Although rooted and un-rooted plantlets acclimatized to soil conditions, great losses were observed within un-rooted plantlets, while the rooted presented $100 \%$ survival. It was possible to maintain $43 \%$ of the $M$. velutina germplasm under healthy conditions for six months, with no subcultures, using the MS medium supplemented with $2 \%$ sucrose, $13.8 \mathrm{mM}$ spermidine, $2 \%$ sorbitol and $2 \%$ dextrose.

Key words: Apocynaceae, Cerrado, medicinal plant

\section{MICROPROPAGAÇÃO, PROPAGAÇÃO POR SEMENTES E BANCO DE GERMOPLASMA DE Mandevilla velutina (Mart.) WOODSON}

\begin{abstract}
RESUMO: Mandevilla velutina (Mart.) Woodson (Apocynaceae) é uma planta medicinal de espécie nativa de regiões do Cerrado brasileiro com propriedades anti-ofídicas. Devido a alta exploração e devastação deste bioma, $M$. velutina está em perigo de extinção. Como uma iniciativa para a conservação desta espécie ameaçada e economicamente importante, um protocolo de micropropagação foi desenvolvido e genótipos foram colocados no Banco de Germoplasma “Cerrado In vitro”. Para a propagação in vitro de M. velutina, segmentos nodais foram inoculados no meio Murashige and Skoog (MS) suplementado com diferentes concentrações de BA, zeatina, 2ip, DTT e TDZ. A melhor resposta de multiplicação foi obtida em meio suplementado com $0.44 \mu \mathrm{M}$ BA na razão 1: 6.7. Plântulas cultivadas em MS/2 suplementado com $26.85 \mu \mathrm{M}$ NAA enraizaram com sucesso (50.5\%). Quando plântulas enraizadas e não enraizadas foram aclimatizadas em condições de solo, grande perda foi observada entre plântulas não enraizadas, enquanto as enraizadas tiveram $100 \%$ de sobrevivência. Foi possível a manutenção de $43 \%$ de $M$. velutina em condições saudáveis por seis meses, sem subculturas usando meio MS suplementado com $2 \%$ de sacarose, $13.8 \mathrm{mM}$ de espermidina, $2 \%$ de sorbitol e $2 \%$ de dextrose.

Palavras-chave: Apocynaceae, Cerrado, planta medicinal
\end{abstract}

\section{INTRODUCTION}

Mandevilla velutina (Mart.) Woodson, a subshrub that belongs to the Apocynaceae family, is a perennial endemic plant from the Brazilian "Cerrado". Apezzato-da-Glória \& Estelita (2000) investigated the nature of the subterranean systems of this species and revealed that it encloses xylopodium and a tuberous root system. The extract of $M$. velutina underground systems is widely used against snake bites and as an anti-inflammatory agent. The anti-inflammatory effect of $M$. velutina aqueous extract was investigated and showed to selectively antagonize bradykinin (Calixto et al., 1985; 1986; 1987), this activity being related to the presence of the triterpene velutinol (Bento et al., 1996). The aqueous extract of subterranean system of 
M. velutina also inhibited the phospholipase, myotoxic, hemorrhagic and edema-inducing activities of snake crude venoms and toxins isolated from Crotalus and Bothrops species (Biondo et al., 2003).

Owing to its high therapeutic potential, Mandevilla velutina has been subjected to intense harvesting causing devastation of native areas and put in risk survival of remaining populations in natural habitats. The aim of this work was to investigate the germination conditions of $M$. velutina seeds, to establish a micropropagation protocol to permit germplasm storage, as an alternative method for the conservation of native plant populations.

\section{MATERIAL AND METHODS}

\section{Propagation by seeds}

The seeds came from fruits of 20 plants randomly collected in the "cerrado" region of Araxá (19 ${ }^{\circ} 36^{\prime} \mathrm{S}$ and $42^{\circ} 08^{\prime} \mathrm{W}, 929 \mathrm{~m}$ altitude), in the Minas Gerais state, Brazil, and were planted in gerboxes containing sterile Plantimax ${ }^{\circledR}$ and kept inside a phytotron under $70 \%$ of relative humidity, $27^{\circ} \mathrm{C}$ and 16 -h photoperiod of intensity $40 \mu \mathrm{mol} \mathrm{m} \mathrm{s}^{-2}$, given by $85 \mathrm{~W}$ cool-white GE fluorescent lamps. The emergence of the radicle was taken as the germination indicator, which was recorded to calculate germination percentage. Ninety-day plantlets were transplanted into pots (2 kg capacity) containing soil: sand (2:1) and kept inside a greenhouse with daily irrigation. Percentage of survival was evaluated two months after replanting. Experiments were carried out with 30 plants and 5 replicates.

The experimental design was fully randomized with five replicates of 50 seeds. Data were analyzed statistically by ANOVA followed by the Tukey test $(P<0.05)$.

\section{Micropropagation}

Plants were also collected in Araxá and a voucher specimen was deposited in the Herbarium of the University of Ribeirão Preto (voucher HPM 013), Ribeirão Preto, SP, Brazil.

Nodal segments harvested from these plants were washed in tap water for $12 \mathrm{~h}$, soaked in $0.2 \%$ $(\mathrm{w} / \mathrm{v})$ Benomyl solution for $24 \mathrm{~h}$ under constant agitation, immersed in 70\% (v/v) alcohol/water for $1 \mathrm{~min}$, and also submerged in $0.5 \%(\mathrm{w} / \mathrm{v})$ calcium hypochlorite solution for $30 \mathrm{~min}$. Disinfested explants were inoculated into glass tubes $(8.5 \mathrm{~cm} \times 2.5 \mathrm{~cm})$ containing $5 \mathrm{~mL}$ of MS culture medium (Murashige \& Skoog, 1962), supplemented with $3 \%$ (w/v) sucrose, jelled with $0.2 \%$ Phytagel $^{\oplus}, \mathrm{pH}$ adjusted to 6.0. Culture flasks were covered with polypropylene closures $\left(\right.$ Bellco $^{\mathrm{TM}}$ ) sealed with a plastic film, autoclaved at $121^{\circ} \mathrm{C}$ and $105 \mathrm{kPa}$ for $15 \mathrm{~min}$, and maintained at $25 \pm 2^{\circ} \mathrm{C}$ and $55-60 \%$ relative humidity under the same photoperiod and light intensity used in the seed propagation.

After two weeks of culture, explants presenting no contamination were subcultured on semisolid MS medium complemented with growth regulators, 6benzyladeninepurine (BA), 2-isopentenyladenine (2ip), Zeatin, thidiazuron (TDZ) and 1,4-dithriothreitol (DTT), in five concentrations (Table 1). After 45 days, explants were evaluated for shoot height and number of shoots per bud. For rooting, MS/2 and MS/4 media, added with indole-3-butyric acid (IBA) or $\alpha$-naphthalene acetic acid (NAA) in two concentrations were compared (Table 2). The adopted experimental design was completely randomized with three replicates and 10 explants per treatment $(n=30)$. Data were statistically analyzed by ANOVA followed by the Tukey test $(P<0.05)$.

For soil acclimatization, rooted and unrooted plantlets, $5 \mathrm{~cm}$ high, were directly transferred from flasks to plastic bags $(50 \times 100 \mathrm{~mm})$ containing soil/ sand mixture (1:3). Each plantlet was covered with a glass test tube $(40 \times 80 \mathrm{~mm})$ and kept inside a greenhouse under shade cloth (50\% light) with daily irrigation. To evaluate plantlet development the growth was measured twice within the period of 90 days.

\section{Germplasm storage}

To establish in vitro plantlet long-term storage conditions, microcuttings were transferred to different culture media to determine the best conditions to assure the survival of vigorous but slow growing plantlets under extended subculture intervals. Undersized plantlets were achieved in MS culture medium, with nutrient concentration reduced to half strength (MS/2), supplemented with $2 \%$ sucrose or $2 \%$ dextrose, plus $3 \%$ mannitol or $4 \%$ sorbitol, and $8.3 \mu \mathrm{M}$ calcium pantothenate or $13.8 \mu \mathrm{M}$ spermidine (Table 3). Cultures were incubated for six months at $18^{\circ} \mathrm{C}$ and 12 -h photoperiod under cool-white GE fluorescent lamps under low light intensity $\left(23 \mu \mathrm{mol} \mathrm{m} \mathrm{m}^{-2}\right)$. After six-months of storage, cultures were analyzed to evaluate plantlet growth and maintenance. A complete randomized experimental design was adopted, with three replicates of 20 explants per treatment. Data were statistically analyzed by ANOVA followed by the Tukey test $(P<0.05)$.

\section{RESULTS AND DISCUSSION}

\section{Propagation by seeds}

Fruits of M. velutina with approximately $28 \mathrm{~cm}$ contain $63 \pm 7$ seeds. Germination is ranged $64 \pm 5 \%$. 
Table 1 - Cytokinin and chemical agent effects on shoot proliferation and in vitro development of M. velutina.

\begin{tabular}{|c|c|c|c|c|}
\hline Cytokinin & Concentration & Shoot height & Number of shoots/bud & Number of buds/stem \\
\hline & $\mu \mathrm{M}$ & $\mathrm{cm}$ & & \\
\hline \multirow[t]{5}{*}{ BA } & 0.44 & $7.96 \mathrm{ab}$ & $1.53 \mathrm{a}$ & $6.74 \mathrm{a}$ \\
\hline & 2.22 & $7.86 \mathrm{ab}$ & $1.50 \mathrm{a}$ & $6.45 \mathrm{a}$ \\
\hline & 4.44 & $8.10 \mathrm{a}$ & $1.36 \mathrm{a}$ & $6.34 \mathrm{a}$ \\
\hline & 13.42 & $4.20 \mathrm{~b}$ & $1.53 \mathrm{a}$ & $3.94 \mathrm{~b}$ \\
\hline & 22.20 & $2.86 \mathrm{~b}$ & $1.36 \mathrm{a}$ & $1.91 \mathrm{c}$ \\
\hline \multirow[t]{5}{*}{ Zeatin } & 0.46 & $5.33 \mathrm{a}$ & $1.56 \mathrm{a}$ & $4.03 \mathrm{~b}$ \\
\hline & 2.28 & $3.80 \mathrm{a}$ & $1.36 \mathrm{ab}$ & $2.23 \mathrm{a}$ \\
\hline & 4.57 & $3.83 \mathrm{a}$ & $1.36 \mathrm{ab}$ & $2.76 \mathrm{a}$ \\
\hline & 13.71 & $4.70 \mathrm{a}$ & $1.00 \mathrm{~b}$ & $3.43 \mathrm{a}$ \\
\hline & 22.85 & $3.06 \mathrm{~b}$ & $1.13 \mathrm{ab}$ & $2.74 \mathrm{a}$ \\
\hline \multirow[t]{5}{*}{2 ip } & 0.49 & $6.00 \mathrm{a}$ & $1.13 \mathrm{a}$ & $4.23 \mathrm{a}$ \\
\hline & 2.46 & $6.16 \mathrm{a}$ & $1.26 \mathrm{a}$ & $4.10 \mathrm{a}$ \\
\hline & 4.93 & $5.36 \mathrm{a}$ & $1.06 \mathrm{a}$ & $4.18 \mathrm{a}$ \\
\hline & 14.79 & $6.43 \mathrm{a}$ & $1.03 \mathrm{a}$ & $4.20 \mathrm{a}$ \\
\hline & 24.65 & $3.93 \mathrm{a}$ & $1.05 \mathrm{a}$ & $3.05 \mathrm{~b}$ \\
\hline \multirow[t]{5}{*}{ DTT } & 0.65 & $4.17 \mathrm{a}$ & $1.73 \mathrm{ab}$ & $3.56 \mathrm{a}$ \\
\hline & 3.24 & $3.93 \mathrm{a}$ & $1.17 \mathrm{~b}$ & $2.54 \mathrm{a}$ \\
\hline & 6.48 & $5.67 \mathrm{a}$ & $1.60 \mathrm{ab}$ & $3.51 \mathrm{a}$ \\
\hline & 19.44 & $5.47 \mathrm{a}$ & $1.83 \mathrm{ab}$ & $2.99 \mathrm{a}$ \\
\hline & 32.40 & $6.70 \mathrm{a}$ & $1.43 \mathrm{a}$ & $3.98 \mathrm{a}$ \\
\hline \multirow[t]{5}{*}{ TDZ } & 0.45 & $3.25 \mathrm{a}$ & $1.40 \mathrm{a}$ & $2.78 \mathrm{a}$ \\
\hline & 2.27 & $2.42 \mathrm{a}$ & $1.17 \mathrm{a}$ & $2.10 \mathrm{a}$ \\
\hline & 4.54 & $3.57 \mathrm{a}$ & $1.17 \mathrm{a}$ & $2.23 \mathrm{a}$ \\
\hline & 13.62 & $3.83 \mathrm{a}$ & $1.33 \mathrm{a}$ & $2.12 \mathrm{a}$ \\
\hline & 22.70 & $4.63 \mathrm{a}$ & $1.00 \mathrm{a}$ & $3.14 \mathrm{a}$ \\
\hline
\end{tabular}

Each treatment was performed in triplicate with ten explants per replicate. Means followed by the same letter do not differ $(P=0.05$, Tukey test).

Table 2 - Growth medium composition effect on rooting of Mandevilla velutina explants.

\begin{tabular}{ccccc}
\hline & Auxin $(\mu \mathrm{M})$ & Medium & Percentage of rooted plants (30 days) & Percentage of rooted plants (90 days) \\
\hline NAA & 0.54 & $\mathrm{MS} / 2$ & $0.50 \mathrm{~b}$ & $4.06 \mathrm{~b}$ \\
& 26.85 & $\mathrm{MS} / 2$ & $12.00 \mathrm{a}$ & $50.50 \mathrm{a}$ \\
& 0.54 & $\mathrm{MS} / 4$ & $3.10 \mathrm{~b}$ & $11.36 \mathrm{~b}$ \\
\hline IBA & 26.85 & $\mathrm{MS} / 4$ & $4.20 \mathrm{~b}$ & $10.43 \mathrm{~b}$ \\
\hline & 24.60 & $\mathrm{MS} / 2$ & $2.86 \mathrm{~b}$ & $8.60 \mathrm{a}$ \\
& 0.49 & $\mathrm{MS} / 2$ & $3.33 \mathrm{a}$ & $5.36 \mathrm{~b}$ \\
& 24.60 & $\mathrm{MS} / 4$ & $2.31 \mathrm{~b}$ & $3.36 \mathrm{~b}$ \\
\hline
\end{tabular}

Each treatment was performed in triplicate with ten explants per replicate. Means followed by the same letter do not differ $(P=0.05$, Tukey test).

No difference was observed for the germination period among all seeds. Radicule arose after 10 days, the first pair of leaves emerged at 25 days, radicule intumescence started after 50 days and root thickness occurred at 90 days (Figure 1). Seedling survival after transplanting to soil reached $74 \%( \pm 6)$.
Results confirm those reported by Appezzato-da-Gloria \& Estelita (2000), who described that the underground system of $M$. velutina comprises a xylopodium presenting a tuberous root in the base and the tuberization process occurs early during growth, when roots are approximately $1 \mathrm{~mm}$ 
Table 3 - Osmotic agent effects on in vitro storage of Mandevilla velutina plantlets during six months.

\begin{tabular}{|c|c|c|c|c|}
\hline Culture medium & $\begin{array}{c}\text { Plant } \\
\text { survival }\end{array}$ & $\begin{array}{l}\text { Shoot } \\
\text { height }\end{array}$ & $\begin{array}{l}\text { Number of } \\
\text { shoots/bud }\end{array}$ & $\begin{array}{l}\text { Number } \\
\text { of buds }\end{array}$ \\
\hline & $\%$ & $\mathrm{~cm}$ & & \\
\hline MS $+2 \%$ sucrose $+4 \%$ sorbitol & $10.0 \pm 0.0$ & $0.38 \mathrm{~b}$ & $0.39 \mathrm{~b}$ & $0.42 \mathrm{ab}$ \\
\hline $\mathrm{MS} / 2+2 \%$ sucrose $+4 \%$ sorbitol & - & - & - & - \\
\hline $\mathrm{MS}+2 \%$ sucrose $+4 \%$ sorbitol $+8.3 \mu \mathrm{M} / \mathrm{L}$ calcium pantothenate & $6.7 \pm 1.15$ & $0.35 \mathrm{~b}$ & $0.32 \mathrm{~b}$ & $0.40 \mathrm{ab}$ \\
\hline $\mathrm{MS} / 2+2 \%$ sucrose $+4 \%$ sorbitol $+8.3 \mu \mathrm{M} / \mathrm{L}$ calcium pantothenate & $17.0 \pm 1.56$ & $0.35 \mathrm{~b}$ & $0.33 \mathrm{~b}$ & $0.33 \mathrm{~b}$ \\
\hline $\mathrm{MS}+2 \%$ sucrose $+3 \%$ mannitol $+8.3 \mu \mathrm{M} / \mathrm{L}$ calcium pantothenate & - & - & - & - \\
\hline $\mathrm{MS} / 2+2 \%$ sucrose $+3 \%$ mannitol $+8.3 \mu \mathrm{M} / \mathrm{L}$ calcium pantothenate & $6.7 \pm 1.15$ & $0.33 \mathrm{~b}$ & $0.32 \mathrm{~b}$ & $0.35 \mathrm{~b}$ \\
\hline $\mathrm{MS}+2 \%$ sucrose $+2 \%$ sorbitol $+2 \%$ dextrose $+13.8 \mu \mathrm{M} / \mathrm{L}$ spermidine & $43.0 \pm 3.46$ & 0.83 a & $0.74 \mathrm{a}$ & $0.77 \mathrm{a}$ \\
\hline $\mathrm{MS} / 2+2 \%$ sucrose $+2 \%$ sorbitol $+2 \%$ dextrose $+13.8 \mu \mathrm{M} / \mathrm{L}$ spermidine & - & - & - & - \\
\hline
\end{tabular}

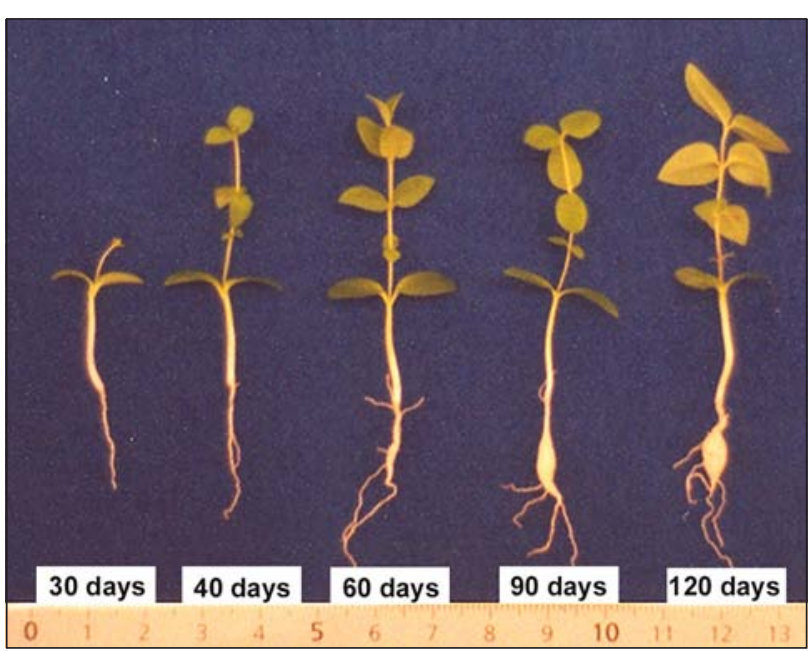

Figure 1 - Mandevilla velutina seedlings from 30 to 120 days after germination.

in diameter, i.e., three months after planting. The precocious tuberization process as verified in Mandevilla is related to the adaptation of the species to the "Cerrado" conditions, which enables the primary root to retain water allowing the species to overcome dry seasons (Rizzini \& Heringer, 1962).

\section{Micropropagation}

Nodal segments excised from seedlings developed regularly in all tested media, no matter the cytokinins and chemical agents used, enhancing stem elongation and lateral bud production. Cytokinins were not effective in inducing multiple shoot proliferation (Table 1). However, BA within the range of 0.44 to $4.44 \mu \mathrm{M}$ was more effective in comparison to the other cytokinins, enhancing shoot elongation and producing tallest plantlets of 7 -cm height. The best medium for shoot growth in relation to shoot height, number of shoot/bud and bud/stem was the MS basal medium complemented with $0.44 \mu \mathrm{M}$ BA.
After 40 days of culture in this medium a multiplication rate of 6.7 buds per stem per explant was achieved.

Thidiazuron (TDZ), a potent growth regulator, considered more active than the BA and Zeatin (ZN), has been recommended for the micropropagation of several species, especially woody species (Lu, 1993). However, our findings do not confirm TDZ's efficiency in breaking apical dormancy of $M$. velutina explants.

In previous studies on micropropagation protocols for "Cerrado" species, we observed that root induction in plantlets cultured in full strength MS medium is not inadequate (Pereira et al., 2003; Biondo et al., 2004). Most of the satisfactory results about shoot rooting have been achieved using half strength MS medium supplemented with auxins (Table 2), though $M$. velutina rooting was partially successful, $50.5 \%$ after 90 days of culture using these nutrients.

Despite of the fact that Auderset et al. (1997) reported the advantageous effects of compounds with SH group-protecting agents such as DTT for enhancing the formation of roots in difficult-to-root woody cuttings, DTT treatments were not effective in rooting M. velutina microcuttings. Handro et al. (1998) reported root formation of $M$. velutina plantlets in full strength MS medium supplemented with auxins but the percentage of rooted and acclimatized plants was not informed.

Unrooted and rooted plantlets can adapt to soil conditions at survival ratios varying between $10 \%$ to $100 \%$, however for a successful development process, M. velutina plantlets need to be rooted. Only 18 months after adaptation to soil, the slow-growing plantlets were able to develop the underground system reaching $1.6 \mathrm{~cm}$ in diameter and $3.6 \mathrm{~cm}$ in depth (Figure 2 ). The underground system of four-month-old plants from germinated seeds presents approximately $1.0 \mathrm{~cm}$ in diameter (Appezzato-da-Glória \& Estelita, 2000), confirming that $M$. velutina is indeed a slow-growing 


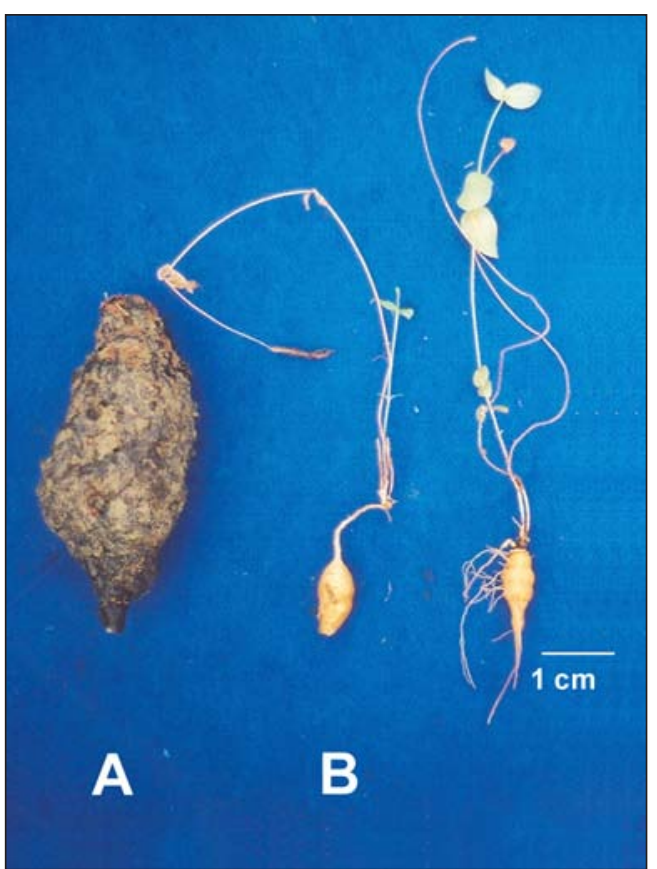

Figure 2 - A) Underground system of Mandevilla velutina adult plant collected in the Brazilian "Cerrado"; B) Underground system of two 18-month Mandevilla velutina micropropagated plants.

species and that the established in vitro protocol did not change both the typical growth of aerial parts and the development characteristics of the underground system.

\section{Germplasm conservation}

The development of $M$. velutina plantlets under germplasm conservation conditions is in Table 3. It is possible to store plantlets under minimal growth and health conditions on MS medium supplemented with $2 \%$ sucrose, $2 \%$ dextrose, $2 \%$ sorbitol and 13.8 $\mu \mathrm{M}$ spermidine. After six months, $43 \%$ of healthy explants tolerate high osmotic conditions. Collin \& Edward (1998) recommended salt reduction to half strength as a means to slow down growth for germplasm storage. However, half strength MS medium supplemented with osmotic agents was not effective for $M$. velutina explants, conversely it contributed to accelerate plantlet growth. Long-term study on in vitro storage of $M$. velutina germplasm still is required to assure that abiotic stresses such as high salt conditions and excessive osmotic pressure do not affect morphological and physiological growth, as McCue \& Hanson (1990) have suggested. Conservation of plant genetic resources is of crucial importance for the continuous availability and improvement of crops. The world germplasm collections of cereals account for $46.8 \%$ of the total, while medicinal plants correspond to only $0.07 \%$ (Villalobos \& En- gelmann, 1995). Indeed, in vitro techniques could facilitate crop improvement and propagation, avoiding future losses in consequence of diseases and attack of pathogens.

\section{Practical implications}

Being considered an endangered species, the use of $M$. velutina by the pharmaceutical industry, in the formulation of phytotherapics would definitely put in risk remaining populations causing the extinction of this species. In this work, viable alternatives for the multiplication were investigated and results demonstrate that $M$. velutina may be propagated by seed and by in vitro organogenesis techniques.

Monitoring of $M$. velutina in the field, for over three years, demonstrated that this species flourishes once a year, during November and December, and each plant produces an average of three to four flowers, but only two to three become fruits. Assays conducted with $M$. velutina seeds determined an average production of 106 seeds per plant, but nearly half of them germinate.

Micropropagation may be a valuable tool for large-scale production of $M$. velutina to supply the pharmaceutical industry without risking natural populations. Also, in vitro plants may be used continually in reforestation programs.

\section{ACKNOWLEDGEMENTS}

To Dr. Rita M. Moraes for technical advice, FAPESP (Projeto Biota No 99/10610), and to the University of Ribeirão Preto - UNAERP, SP, Brazil for financial support.

\section{REFERENCES}

APEZZATO-DA-GLÓRIA, B.; ESTELITA, M.E.M. The developmental anatomy of the subterranean system in Mandevilla illustris (Vell.) Woodson and M. velutina (Mart. Ex Stadelm) Woodson (Apocynaceae). Revista Brasileira Botânica, v.23, p.27-35, 2000.

AUDERSET, G.; MONCOUSIN, C.; O'RROURKE, J.; JAMES MORRE, D. Stimulation of root formation in difficult-to-root woody cuttings by Dithiothreitol. International Journal of Plant Science, v.158, p.132-135, 1997.

BENTO, E.S.; CALIXTO, J.B.; HAWKES, G.E.; PIZZOLATTI, M.G.; SANT'ANA, A.E.G.; YUNES, R.A. The structure of velutinol A is (15R, 16R, 20S)-14,16: 15,20: 16,21-triepoxy- 15,16-seco14beta,17alfa-pregn-5-ene-3beta,15-diol. Journal of the Chemical Society Perkin Transactions, v.2, p.1359-1366, 1996.

BIONDO, R.; PEREIRA, A.M.S.; MARCUSSI, S.; PEREIRA, P.S.; FRANÇA, S.C.; SOARES, A.M. Inhibition of enzymatic and pharmacological activities of some snake venoms and toxins by Mandevilla velutina (Apocynaceae) aqueous extract. Biochimie, v.85, p.1017-1025, 2003.

BIONDO, R.; SOARES, A.M.; BERTONI, B.W.; FRANÇA, S.C.; PEREIRA, A.M.S. Direct organogenesis of Mandevilla illustris (Vell) woodson and effects of its aqueous extract on the enzymatic and toxic activities Crotalus durissus terrificus snake venom. Plant Cell Reports, v.22, p.549-552, 2004. 
CALIXTO, J.B.; NICOLAU, M.; YUNES, R.A. A selective antagonist of bradykinin action from a crude extract of Mandevilla velutina. Effect on isolated rat uterine smooth-muscle. Brazilian Journal of Medical and Biological Research, v.18, p.A728-A728, 1985.

CALIXTO, J.B.; NICOLAU, M.; TREBIEN, H.; ENRIQUE, M.G.O.; WEG, V.B.; CORDEIRO, R.S.B.; YUNES, R.A. Antiedematogenic actions of a hydroalcoholic crude water-alcohol extract of Mandevilla velutina. Brazilian Journal of Medical and Biological Research, v.19, p.A575-A575, 1986.

CALIXTO, J.B.; NICOLAU, M.; PIZZOLATTI, M.G.; YUNES, R.A. Kinin antagonist activity of compounds from Mandevilla velutina in the rat isolated uterus. British Journal of Pharmacology, v.91, p.199-204, 1987.

COLLIN, H.A.; EDWARD, S. Plant cell culture. Oxford: BIOS Scientific Publishers, 1998.

HANDRO, W.; FLOH, E.I.S.; FERREIRA, C.M.; GUERRA, M.P. Tissue, cell culture and micropropagation of Mandevilla velutina, a natural source of a bradykinin antagonist. Plant Cell Reports, v.7, p.564-566, 1998.

LU, C.Y. The use of thidiazuron in tissue culture. In Vitro Cellular \& Developmental Biology, v.29, p.92-96, 1993.
MCCUE, H.F.; HANSON, A.D. Drought and salt tolerance: towards understanding and application. Trends in Biotechnology, v.8, p.358362, 1990.

MURASHIGE, T.; SKOOG, F.A. Revised medium for rapid growth and bioassays with tobacco tissue cultures. Physiologia Plantarum, v.15, p.473-497, 1962.

PEREIRA, A.M.S.; AMUI, S.F.; BERTONI, B.W.; MORAES, R.M.; FRANÇA, S.C. Micropropagation of Anemopaegma arvense: conservation of an endangered medicinal plant. Planta Médica, v.69, p.571-573, 2003.

RIZZINI, C.T.; HERINGER, E.P. Studies on the underground organs of trees and shrubs from some southern Brazilian savannas. Anais da Academia Brasileira de Ciências, v.34, p.235-247, 1962.

VILLALOBOS, V.M.; ENGELMANN, F. Ex situ conservation of plant germplasm using biotechnology. World Journal of Microbiology \& Biotechnology v.11, p.375-382, 1995.

Received August 02, 2006

Accepted March 03, 2007 